DOI: https://doi.org/10.24144/2409-6857.2018.1(51).217-222

УДК 330.12:338.12.021:339.372.84:33.025

Гуштан Т.В., Лазур С.П., Лалакулич М. Ю.

\title{
ІНСТРУМЕНТАРІЙ УПРАВЛІННЯ ТОВАРНИМ АСОРТИМЕНТОМ ТОРГОВЕЛЬНИХ МЕРЕЖ
}

\begin{abstract}
У статті проаналізовано основні економіко-математичні моделі і методи, щуо використовуються в управлінні асортиментом торговельних мереж. Окреслено найбільи потирені інструменти оцінок на привабливість для споживачів перед виводом нового товару на ринок, зокрема: модель Розенберга, модель ідеальної крапки, модель “товарної системи”, моделі спожсивацького вибору. Наведені методи прогнозування фінансових результатів діяльності. Визначено, щзо вибір методів управління асортиментом, в першу чергу, залежить від рівня, на якому здійснюеться процес управління - на стратегічному або тактичному.
\end{abstract}

Ключові слова: економіко-математичні моделі і методи, асортимент, маркетинг, товарна стратегія, програмування, попит, споживачі, конкурентоспроможність, якість, планування.

Постановка проблеми. Вітчизняний ринок роздрібної торгівлі за останні роки став більш концентрованим. На сучасному етапі поступового виходу українського ринку з кризового становища у торговельній галузі спостерігається перехід на нові методи управління. Удосконалення управління торговельними процесами необхідно здійснювати на основі оптимізації існуючої взаємодії виробника і торговельної мережі. Зміни традиційних взаємин між постачальником i ритейлером пов'язані з переходом від конфронтації до кооперації, коли ключовим мотивом для об'єднання зусиль є потреби і запити кінцевих споживачів товару.

Аналіз останніх досліджень і публікацій. Проблеми управління товарним асортиментом торговельної мережі та його моделювання розглянуті у роботах багатьох науковців як зарубіжних, так i вітчизняних: О. Азарян, Л. Балабанової, Р. Вінера, Д. Гілберта, Ф. Котлера, Д. Леманна та ін. Управління товарним асортиментом торговельної мережі зазвичай відбувається інтуїтивно, а не на основі використання наукових методів. Таким чином, питання, пов'язані 3 вибором конкретного інструментарію управління товарним асортиментом, який би найліпше дозволив вирішити проблеми формування асортименту,

(C) Гуштан Тетяна Вікторівна, к.е.н., доцент кафедри товарознавства та комерційної діяльності, Ужгородський торговельно-економічний інститут Київського національного торговельно-економічного університету, м. Ужгород

Лазур Сергій Петрович, к.е.н., доцент кафедри фінансів, Ужгородський торговельно-економічний інститут Київського національного торговельноекономічного університету, м. Ужгород

Лалакулич Марія Юріївна, к.е.н., доцент Ужгородського торговельно-економічного інституту, Київського національного торговельно-економічного університету, м. Ужгород залишається вивченим недостатньо i тому потребує подальшого дослідження.

Формулювання цілей статті. Мета статті визначити інструментарій управління товарним асортиментом торговельних мереж.

Опис основного матеріалу дослідження. Будь-яке управління в економіці пов'язано 3 виробленням і прийняттям управлінських рішень, що втілюються в управлінські впливи. У ході пошуку та аналізу можливих управлінських рішень, вибору кращого з них, суб'єкти управління повинні відібрати найкращий варіант, як реально "спрацює" прийняте рішення i які будуть його наслідки. Перш ніж приймати остаточне рішення доцільно перевірити його дієвість і наслідки на основі побудови економіко-математичної моделі.

Слід відзначити, що впровадження і використання економіко-математичних методів в практиці управління торговельними підприємствами просуваються повільними темпами, ступінь їх застосування набагато нижче потенційно можливого, а вплив на якість управлінських робіт ще недостатній.

Для того, щоб визначити адекватний для підприємства метод дослідження, необхідно сформувати покрокову комплексну модель управління асортиментом, яка потребує визначення області застосування, об'єктів моделювання, використання економікоматематичних методів, а також повинна бути проста у застосуванні i дозволити отримати максимально правдоподібні результати.

Серед економіко-математичних моделей i методів прийняття управлінських рішень на ринку товарів i послуг виділяють такі основні класи: оптимізаційні моделі (лінійне програмування, нелінійне програмування, дискретне програмування, стохастичне програмування, динамічне програмування); методи математичної статистики (кореляційно-регресійні моделі, метод Монте-Карло, баєсовський підхід, факторний 
аналіз, дисперсійний аналіз); багатостадійні моделі прийняття рішень (дерева рішень, марківські моделі, теорія графів); моделі споживчого попиту; теорію ігор; теорію зв'язків; теорію управління запасами; теорію масового обслуговування; нейромережні моделі; економетричні моделі; імітаційні моделі; методи аналізу часових рядів; оцінні методи; методи мережного планування; нечіткомножинний підхід; дослідження операцій.

Традиційні методи багатокритерійної оптимізації (метод головного критерію, метод лінійної згортки, метод максимінної згортки та ін.) досить добре вивчені в математиці та економіці, $\mathrm{i}$ можуть застосовуватися для оптимального вибору певних параметрів управління. Тому вони служать скоріше технічним засобом пошуку оптимального рішення детально проаналізованої проблеми за умови формулювання функціоналів i допустимої множини значень.

Недоліком багатокритерійної постановки задач, в яких функціонал виражається у вигляді адитивної або мультиплікативної згортки параметрів ефективності, $\epsilon$ можливість компенсації недоліку одних якостей за рахунок надлишку інших.

Лінійне програмування як математичний метод для вибору найсприятливішого рішення (3 мінімальними витратами, максимальним прибутком, найменшим витратами часу або зусиль) застосовується в маркетингу, наприклад при розробці більш вигідного асортименту в умовах обмежених ресурсів, розрахунку оптимальної величини товарних запасів, плануванні маршрутів руху збутових агентів [9].

Метод ділових ігор значною мірою допомагає вирішенню реальних маркетингових ситуацій, що дозволяе “програвати” при пошуку оптимальних варіантів спрощені моделі поведінки конкурентів і стратегії виходу на нові ринки [9].

Маркетингові дослідження поведінки споживачів 3 метою подальшого сегментування ринку $\epsilon$ обов'язковим етапом стратегічного маркетингу. Саме на цільовий ринок спрямовується основна маркетингова діяльність підприємства. Визначення профілю сегменту складний процес, тому доречним $є$ використання методів економіко-математичного моделювання, які дозволяють формалізувати процес систематизації ознак споживача. Г.С. Решетніковою та А.Б. Жидковим наведені результати досліджень цієї тематики, отриманих з використанням побудови “Дерев рішень” [12]. Крім того, метод “Дерево рішень” використовується для оцінки ризиків.

Кравченко В.Н. і Руденским Р.А. запропоновано підхід до оцінки маркетингового потенціалу підприємства і прогнозування ринкової ситуації 3 використанням ланцюгів Маркова. Недоліком даного методу $є$ обов'язкова наявність даних (часто засекречених), що надаються зовнішніми інформаційно-аналітичними організаціями про конкурентів [7].

Відомі методи кількісного аналізу управлінських рішень не завжди відповідають вимогам забезпечення необхідної в практичному маркетингу точності i надійності оцінок ефективності і ступеню ризику стратегій для підприємств. Песиковим Е.Б. запропоновано метод оцінки ефективності i ступеня ризику стратегій з використанням статистичної імітаційної моделі функціонування підприємства, що характеризується можливістю обліку стохастичності параметрів зовнішнього середовища, дії реклами на об'єми продажів і впливу чинників конкурентного середовища. Дана імітаційна модель функціонування підприємства заснована на застосуванні широкого спектру розподілів випадкових параметрів. Застосування моделі Відаля-Вольфа, дозволяе підвищити ефективність маркетингових стратегій і точність оцінок ризику [11].

Найточніша оцінка ефективності i ризику може бути отримана при відомому розподілі ймовірностей випадкових параметрів зовнішнього середовища. Розподіл можна отримати на підставі статистичних даних про стан зовнішнього середовища в попередні часові періоди. Якщо підприємство не має такої статистики або вона недостатня для надійної оцінки параметрів розподілу досліджуваних показників, то доцільно використовувати метод Монте-Карло. Комплексний підхід до оцінки ризику, що реалізується при застосуванні методу Монте-Карло, полягає в тому, що для аналітика представляється можливим аналізувати різні вимірники ризику: розподіл ймовірностей, оцінки математичного очікування, середньоквадратичного відхилення і коефіцієнта варіації, ймовірності попадання значення вихідного показника в заданий інтервал.

Широке розповсюдження для вирішення маркетингових задач отримав "Байєсовський підхід”. Доцільність його застосування пов'язана 3 рішенням задач в умовах ризику, неповної інформації і невизначеності, тобто тоді, коли менеджер не може точно визначити ймовірність виникнення різних ситуацій, які необхідно враховувати, оскільки вони впливають на вибір рішення [8].

Для моделювання товарної стратегії підприємства Литвиненко С.В. представлена апроксимаційна оцінка тренда часового ряду. Мета цього методу - отримати компоненти тренда, які в майбутньому будуть однорідними i 
точними на початкову дату. Цей метод дозволяє розраховувати згладжений тренд, що дуже вигідно в різних структурах діяльності торговельного підприємства, а також дозволяє розрахувати оптимальну партію продажу товару [8].

Для комплексного вирішення задач, пов'язаних 3 підвищенням якості продукції i одночасній економії матеріальних і трудових ресурсів, використовується метод кореляційнорегресійного аналізу. Застосування цього методу дозволяє підприємствам знайти такі раціональні рішення в області обслуговування процесів реалізації товарів, які забезпечать підвищення конкурентоспроможності маркетингової системи. Але використання даного методу доцільно у випадках стійкої екстраполяційної спрямованості досліджуваних маркетингових показників. Тобто, коли апріорно відомо, що діяльність в минулому періоді мала тенденцію, яка збереглася в майбутньому періоді, емпіричні ряди маркетингових показників повинні бути достатньо тривалими для виявлення статистично достовірної залежності.

Для короткострокових ринкових прогнозів часто використовують оцінні методики. При складанні прогнозів для незначних часових інтервалів відхилення, характерні для оцінних методик, у меншій мірі спотворюють результати, ніж у випадку з більш тривалими горизонтами прогнозування. Крім того, оцінні методи використовуються для прогнозу поведінки і реакції конкурентів.

Застосування математичних моделей для аналізу маркетингової діяльності торговельного підприємства або при дослідженні ринків надають істотну допомогу розробникам бізнеспланів. А. Недосекин і А. Овсянко висунули основні положення про використання математики нечітких множин до задач маркетингового моделювання [10].

На даний момент все більшою популярністю користуються моделі на основі нейронних мереж. Основна їхня перевага у моделюванні процесів, важко придатних до формалізації, полягає у тому, що їх застосування усуває необхідність проводити кореляційний та інші форми аналізу. Крім того, на користь нейронних мереж свідчить те, що для їхньої побудови можна використовувати не тільки кількісні показники, а й якісні. Це є особливо важливим для моделювання маркетингових процесів, де вхідні дані часто надходять у результаті анкетування саме у текстовій формі. Застосування нейронних мереж дозволяє прогнозувати поведінку споживачів певного ринку щодо торговельної марки та зміну їхніх переваг у разі зміни стратегії марки [12]. Водночас нейронні мережі не дають змоги проаналізувати, які саме чинники, пов'язані 3 особистістю споживача, більше впливають на рівень прихильності до торговельної марки.

При вирішенні проблем вибору черговості обслуговування замовників, складання графіків поставок товарів i інших аналогічних задач застосовуються методи теорії масового обслуговування, які дають можливість, поперше, вивчити ті закономірності, що пов'язані 3 наявністю потоку заявок на обслуговування, i, по-друге, дотримати необхідну черговість їх виконання.

Теорія зв'язку, що розглядає механізм “зворотних зв'язків”, дозволяє отримати сигнальну інформацію про процеси, що виходять за межі встановлених параметрів. В маркетинговій діяльності використання цього підходу дає можливість управляти товарними запасами та процесами реалізації. Застосування теорії зв'язку в організаційних структурах маркетингової діяльності допомагає удосконалити зв'язок підприємств 3 ринком, підвищити ефективність використовування отриманих даних.

Метод мережного планування дає можливість регулювати послідовність i взаємозалежність окремих видів робіт або операцій в рамках будьякої програми, дозволяє чітко фіксувати основні етапи роботи, визначати терміни їх виконання, розмежовувати відповідальність, економити витрати, передбачати можливі відхилення. Цей метод ефективний при організації пробних продажів, підготовці i проведенні рекламних кампаній.

Перед виведенням нового товару на ринок доцільно провести оцінки на привабливість для споживачів. 3 теорії маркетингу найбільш поширені інструменти таких оцінок: модель Розенберга (грунтується на оцінці нового товару споживачами 3 погляду його придатності для задоволення потреб), модель ідеальної крапки (грунтується на штучному введенні нового компоненту, який $\epsilon$ ідеальним 3 погляду споживача i найбільш повно відображає характеристику нового товару; іншим варіантом цієї моделі $є$ оцінка рівня задоволення потреб споживача, в якій оцінюється відношення рівня очікування споживачів до реального рівня задоволення їх потреб) та модель “товарної системи” (грунтується на тому, що потреби, які увійшли до “товарної системи" мають різний рівень важливості для споживача, а значущість цих потреб різниться для різноманітних сегментів споживачів, це дає змогу оцінки ваги конкретних потреб й оцінки потреби на 
конкретному сегменті ринку).

Широко відомі моделі споживацького вибору такі, як модель вибору по очікуваній значущості, яка припускає, що споживач додає певну вагу своєму уявленню про конкретний товар i значущість окремих ознак; модель вибору на основі порівняльної переваги, яка спирається на зіставлення властивостей вибраного товару 3 деяким товаром, відповідним повному задоволенню потреб; лексикографічна модель вибору, що припускає ранжирування споживачем властивостей товару в порядку їх значущості; а також модель вибору в ситуації 3 ризиком, поширена в ділових відносинах, характерних для ситуацій 3 ризиком. Споживачі прагнуть отримати перевагу за придбання прав на власність, отримання ліцензій, контрактів і т.д.

Успіх маркетингової стратегії залежить від точного прогнозу поведінки i реакції конкурентів. Для прогнозування поведінки конкурентів доцільно використовувати оцінні і статистичні методи. Наступний крок після прогнозування дій - прогноз їх впливу на об' $е м$ ринку і ринкову частку компанії. Для створення успішної маркетингової стратегії дуже важливо також передбачати дії постачальників, дистриб'юторів, держави і інших зацікавлених сторін. Крім того, не менш важливою є реакція внутрішньої аудиторії, тобто, співробітників торговельного підприємства. Недостатність ресурсів, неправильне уявлення про мету, опір зацікавлених сторін або порушення зобов'язань призводить до труднощів здійснення маркетингових стратегій. Подібних проблем можна запобігти за допомогою якісних методів прогнозування.

Щодо методів прогнозування, то слід зазначити, що серед них $\epsilon$ методи цілком доступні для використання в практиці, а також методи, що вимагають від фахівця серйозної математичної підготовки. На жаль, на практиці прогнозування зводиться до виведення середніх продажів за період, і на основі цього складається замовлення на поповнення складу. При прогнозуванні продажів для підвищення точності прогнозу необхідно провести опитування споживачів. Дані про наміри покупців можна використовувати для підвищення точності екстраполяції. Крім того, важливу роль в прогнозуванні фінансових результатів діяльності грає правильна оцінка витрат при складанні маркетингового плану. Для прогнозування витрат на стійкому ринку часто використовують метод екстраполяції.

Якщо на ринку плануються кардинальні зміни, для прогнозування більш застосовні експертні методи, а в деяких випадках використовують економетричні моделі. Але дані методи дозволяють скласти високоточний прогноз лише на тривалий термін. Науковці докладають чимало зусиль для короткострокового прогнозування, але ця сфера застосування даних методів не демонструє вражаючих результатів.

Вибір методів управління асортиментом, в першу чергу, залежить від рівня, на якому здійснюється процес управління, - на стратегічному або тактичному. На стратегічному рівні приймаються рішення, пов'язані з вибором стратегії управління асортиментом відповідно до ринкової кон'юнктури. На тактичному рівні здійснюється вибір конкретних асортиментних позицій, виходячи з рівня попиту і економічних показників по кожній позиції.

Основною метою реалізації стратегії управління товарним асортиментом $є$ збільшення долі задоволеного попиту цільового сегменту споживачів за рахунок оптимізації структури асортименту.

Висновки i перспективи подальших досліджень. Впровадження i використання економіко-математичних методів в практиці управління торговельними підприємствами просуваються повільними темпами, ступінь їх застосування нижче потенційно можливої, а вплив на якість управлінських робіт недостатній. Для цього необхідно сформувати покрокову комплексну модель управління асортиментом. Використання економіко-математичних методів повинно бути простим у застосуванні. Вибір методів управління асортиментом залежить від рівня, на якому здійснюється процес управління - на стратегічному або тактичному.

Головною метою реалізації стратегії управління товарним асортиментом $є$ збільшення частки задоволеного попиту цільового сегменту споживачів за рахунок оптимізації структури асортименту. Вибір конкретного інструментарію управління товарним асортиментом дозволить підприємствам вирішити проблеми формування асортименту, розв'язати задачі, пов'язані 3 підвищенням якості продукції i одночасною економією матеріальних і трудових ресурсів, знайти раціональні рішення в сфері обслуговування процесів реалізації товарів, які забезпечать підвищення конкурентоспроможності маркетингових систем, збільшити показники прибутку і товарообігу за рахунок максимального розширення асортименту шляхом введення брендових товарів і покращення співвідношення ціни та якості. 


\section{ПЕРЕЛІК ВИКОРИСТАНИХ ДЖЕРЕЛ}

1. Важинський Ф.А. Диверсифікація та кооперація розвитку сільських територій регіону / Ф.А. Важинський, А.В. Колодійчук, О.С. Молнар // Науковий вісник Ужгородського університету : зб. наук. пр. - Сер.: Економіка. - 2011. - Вип. 33, ч. 3. - С. 125-129.

2. Важинський Ф.А. Маркетингові дослідження в системі управління конкурентоспроможністю підприємств / Ф.А. Важинський, А.В. Колодійчук // Науковий вісник НЛТУ України. - 2009. - Вип. 19.1. C. $125-130$.

3. Важинський Ф.А. Механізм регулювання інвестиційної діяльності в регіоні / Ф.А. Важинський, А.В. Колодійчук // Науковий вісник НЛТУ України : зб. наук.-техн. праць. - Львів: РВВ НЛТУ України. - 2010. - Вип. 20.7. - С. 138-143.

4. Важинський Ф.А. Оцінка ефективності управління системою збуту машинобудівних підприємств / Ф.А. Важинський, Л.С. Ноджак, А.В. Колодійчук // Економіка промисловості. - 2010. - № 1. - С . $119-122$.

5. Гоголь Г.П. Сутність збутової діяльності машинобудівних підприємств / Г.П. Гоголь, А.В. Колодійчук, А.Ю. Яремко // Науковий вісник НЛТУ України: зб. наук.-техн. праць. - 2010. - Вип. 20.7. - С. 148-153.

6. Долішній I.M. Мотивація персоналу як об'єкт управління на підприємстві / I.М. Долішній, А.В. Колодійчук // Науковий вісник НЛТУ України: зб. наук.-техн. праць. - 2010. - Вип. 20.5. - С. 211-216.

7. Кравченко В.Н. Оценка маркетингового потенциала предприятия с использованием цепей Маркова / В.Н. Кравченко, Р.А. Руденский // Управление маркетинговым потенциалом предприятия. - Донецк: ДонНУ, 2003. - №2. - C.12-25.

8. Литвиненко С.В. Моделирование товарной стратегии предприятия / С.В. Литвиненко // Модели управления в рыночной экономике: сб. науч. тр.; общ. ред.и предисл. Ю.Г. Лысенко; Донец. гос. ун-т. - Донецк: ДонГУ, 1999. - С.202-207.

9. Максимова Т.С. Діагностика динамічних процесів розвитку комплексу маркетингу / Т.С. Максимова, О.С. Шапран // Актуальні проблеми економіки. - 2007. - №8 (74). - С.124-131.

10. Недосекин А. Нечетко-множественный подход в маркетинговых исследованиях [Электронный ресурс] / А. Недосекин, А. Овсянко. - Консультационная группа “Воронов и Максимов”. - Режим доступа: http://www.aup.ru/articles/marketing/15.htm

11. Песиков Э.Б. Оценка эффективности и степени риска маркетингових стратегий предприятия на основе имитационного моделирования [Электронный ресурс] / Э.Б. Песиков. - Режим доступа: http://www.gpss.ru/immod\%2703/068.html

12. Решетнікова Г.С. Нейронні мережі як засіб аналізу і моделювання поведінки споживача / Г.С. Решетнікова, А.Б. Жидков // Маркетинг в Україні. - 2007. - №3. - С.22-27.

\section{REFERENCES}

1. Vazhynskyy, F. A., Kolodiychuk, A. V., \& Molnar, O. S. (2011). Dyversyfikatsiya ta kooperatsiya rozvytku sil's'kykh terytoriy rehionu [Diversification and co-operation of the development of rural areas of the region]. In Naukovyy visnyk Uzhhorods'koho universytetu. Seriya: Ekonomika [Scientific Bulletin of Uzhhorod University. Series: Economics]: Vol. 33.3 (pp. 125-129). [in Ukrainian].

2. Vazhynskyy, F. A., \& Kolodiychuk, A. V. (2009). Marketynhovi doslidzhennya v systemi upravlinnya konkurentospromozhnistyu pidpryyemstv [Marketing Research in the System of Competitiveness Management of Enterprises]. In Naukovyy visnyk NLTU Ukrayiny [Scientific Bulletin of National Forestry University of Ukraine]: Vol. 19.1 (pp. 125-130). [in Ukrainian].

3. Vazhynskyy, F. A., \& Kolodiychuk, A. V. (2010). Mekhanizm rehulyuvannya investytsiynoyi diyal'nosti v rehioni [Mechanism for regulation of investment activity in the region]. In Naukovyy visnyk NLTU Ukrayiny [Scientific Bulletin of National Forestry University of Ukraine]: Vol. 20.7 (pp. 138-143). [in Ukrainian].

4. Vazhynskyy, F. A., Nodzhak, L. S., \& Kolodiychuk, A. V. (2010). Otsinka efektyvnosti upravlinnya systemoyu zbutu mashynobudivnykh pidpryyemstv [Estimation of efficiency of management of system of sale of machine-building enterprises]. Ekonomika promyslovosti - Economy of Industry, 1, 119-122. [in Ukrainian].

5. Hohol, H. P., Kolodiychuk, A. V., \& Yaremko, A.Yu. (2010). Sutnist' zbutovoyi diyal'nosti mashynobudivnykh pidpryyemstv [The essence of the sales activities of machine-building enterprises]. In Naukovyy visnyk NLTU Ukrayiny [Scientific Bulletin of National Forestry University of Ukraine]: Vol. 20.7 (pp. 148-153). [in Ukrainian].

6. Dolishniy, I. M., \& Kolodiychuk, A. V. (2010). Motyvatsiya personalu yak ob"yekt upravlinnya na pidpryyemstvi [Motivation of the personnel as an object of management in the enterprise]. In Naukovyy visnyk NLTU Ukrayiny [Scientific Bulletin of National Forestry University of Ukraine]: Vol. 20.5 (pp. 211-216). [in Ukrainian].

7. Kravchenko, V. N., \& Rudenskiy, R. A. (2003). Otsenka marketingovogo potentsiala predpriyatiya s ispol'zovaniyem tsepey Markova [Estimation of the marketing potential of the enterprise using the Markov chains]. In Upravleniye marketingovym potentsialom predpriyatiya [Management of Marketing Potential of the Enterprise]: Vol. 2 (pp. 12-25). [in Russian].

8. Litvinenko, S. V. (1999). Modelirovaniye tovarnoy strategii predpriyatiya [Modeling of commodity strategy of the enterprise]. In Modeli upravleniya v rynochnoy ekonomike [Models of Management in a Market Economy] (pp. 202-207). [in Russian]. 
9. Maksymova, T. S., \& Shapran, O. Ye. (2007). Diahnostyka dynamichnykh protsesiv rozvytku kompleksu marketynhu [Diagnostics of dynamic processes of marketing complex development]. Aktual'ni problemy ekonomiky Actual Problems of Economics, 8 (74), 124-131. [in Ukrainian].

10. Nedosekin, A., \& Ovsyanko, A. (1999). Nechetko-mnozhestvennyy podkhod v marketingovykh issledovaniyakh [Fuzzy-multiple approach in marketing research]. Retrieved from http://www.aup.ru/articles/marketing/15.htm [in Russian].

11.Pesikov, E. B. (2002). Otsenka effektivnosti i stepeni riska marketingovikh strategiy predpriyatiya na osnove imitatsionnogo modelirovaniya [Estimation of efficiency and degree of risk of marketing strategies of the enterprise on the basis of imitating modeling]. Retrieved from http://www.gpss.ru/immod\%2703/068.html [in Russian].

Reshetnikova, H. S., \& Zhydkov, A. B. (2007). Neyronni merezhi yak zasib analizu i modelyuvannya povedinky spozhyvacha [Neural networks as a means of analyzing and modeling consumer behavior]. Marketynh v Ukrayini Marketing in Ukraine, 3, 22-27. [in Ukrainian].

Одержано 15.03.2018 p. 